\title{
Evaluation of Child Refugees' Reasons for Applying to Hospital: Ankara Experience
}

\section{Çocuk Mültecilerin Hastaneye Başvuru Nedenlerinin Değerlendirilmesi: Ankara Deneyimi}

\author{
Zahide Yalaki', Medine Aysin Tasar'1, Rukiye Sac', Arife Uslu Gokceoglu' \\ DFiliz Simsek Orhon²
}

'Saglik Bilimleri Üniversitesi, Ankara Egitim ve Arastirma Hastanesi, Ankara, Turkey

${ }^{2}$ Ankara University, Faculty of Medicine, Department of Pediatrics , Ankara, Turkey

\begin{abstract}
Aim: The aim of this study was to identify the diagnosis characteristics of the refugees who applied to pediatric emergency and pediatric outpatient polyclinics of a major hospital in Ankara.

Material and Method: Files of patients admitted to the pediatric emergency and pediatric outpatient clinics between January and December of 2017 were analyzed retrospectively.

Results: There were 12385 refugee applications to the pediatric emergency clinic during this period. The number of refugee applications to the outpatient pediatrics clinic was 8341 . The distribution of the nationality of the refugee children who applied to the emergency clinic was $46.2 \%$ Syrian, 50.6\% Iraqi, 1.2\% Afghan, and $2 \%$ from other countries. The distributions of the nationality of the refugee children who applied to the pediatric outpatient polyclinic were $51.9 \%$ Syrian, $45.9 \%$ Iraqi, 0.9\% Afghan, and $1.3 \%$ from other countries. The most frequent diagnosis of refugee children admitted to the pediatric emergency clinic and pediatric outpatient polyclinics were upper respiratory tract infections and lower respiratory tract infections. $21.4 \%$ of the refugee patients who applied to the emergency clinic were admitted to the pediatric clinic or the pediatric intensive care unit. Of these patients, 1.1\% were hospitalized for Varicella and $0.8 \%$ were hospitalized for Hepatitis A. Anemia of iron deficiency was observed in $23.8 \%$, vitamin B12 deficiency was observed in 9.6\%, and malnutrition was observed in $6.2 \%$ of the patients.

Conclusions: We recommend that every refugee child should be scanned for malnutrition and anemia and nutritional support should be provided to preserve their health.
\end{abstract}

Keywords: Child, refugee, anemia, infection
Öz

Amaç: Ankara'da büyük bir hastanenin çocuk acil ve genel çocuk polikliniklerine başvuran mültecilerin aldıkları tanılarının araştırılması amaçlandı.

Gereç ve Yöntem: Ocak ve Aralık 2017 tarihleri arasında çocuk acil ve genel çocuk polikliniklerine başvuran hastaların dosyaları retrospektif olarak incelendi.

Bulgular: Bu dönemde çocuk acil polikliniğine 12.385 mülteci başvurusu yapılmıştır. Genel çocuk polikliniklerine ise 8.341 mülteci başvurmuştur. Acile başvuranların \%46,2'si Suriye, \%50,6'sı Irak, \%1,2'si Afgan ve \%2'si diğer ülkelerden gelen mültecilerdi. Genel çocuk polikliniğine başvuranların ise \%51,9'u Suriye, \%45,9'u Irak, \%0,9'u Afgan ve \%1,3'ü diğer ülkelerden gelen mültecilerdi. Çocuk acil polikliniği ve genel polikliniklere yapılan başvurularda en sık konulan tanı üst solunum yolu ve alt solunum yolu enfeksiyonlarıydı. Acile başvuran mültecilerin \%21,4'ü çocuk kliniği veya yoğun bakımına kabul edildi. Bu hastaların \%1,1'i suçiçeği ve \%0,8'i hepatit A nedeniyle yatırıldı. Hastaların \%23,8'inde demir eksikliğine bağlı anemi, \%9,6'sında B12 vitamini eksikliği ve \%6,2'sinde malnutrisyon saptandı.

Sonuç: Her mülteci çocuğun yetersiz beslenme ve anemi için taranmasını ve sağlığını korumak için beslenme desteğinin sağlanması gerektiğini öneriyoruz.

Anahtar Kelimeler: Çocuk, mülteci, anemi, enfeksiyon 


\section{INTRODUCTION}

In recent years, millions of people were forced to leave their own country to seek refuge in other countries, because of economic, social, and political reasons, especially wars. With the ongoing wars in the Middle East, especially in Syria, millions of refugees are trying to live without social security and in unstable conditions in foreign countries where they do not know and understand the language. ${ }^{[1,2]}$

In Turkey, there is a large number of refugees and most of them come from Syria and Afghanistan. According to the United Nations High Commissioner for Refugees, more than 2.7 million Syrian refugees are registered in Turkey as of June 2016. This number has exceeded 3.5 million in 2018, according to the Interior Ministry's Immigration Administrations General Directorate data. ${ }^{[3,4]}$ Some refugees remain at the camps close to the border in Turkey. Some of them migrate to different cities in the country and share a house where they can live in partnership with other refugee families. According to the Ministry of Interior's 2018 data, there are 227075 Syrian refugees in the camps. As many as 3334632 refugees have migrated to cities outside the camps. Many refugees have poor nutrition, poor living conditions, difficulty in accessing health facilities, language problems, and low educational levels; all of which cause adverse health consequences. Thus, health problems such as bacterial and viral respiratory tract infections, gastroenteritis and soft tissue infections are common among refugees. ${ }^{[1,3,5-7]}$

When we consider the age range of the refugees, the majority of them are children under the age of 18, especially children under the age of five..$^{[3,8,9]}$ Due to lack of regular childhood vaccination, refugee children are vulnerable to infectious diseases and they can cause infectious disease epidemics in their host countries. ${ }^{[10,11]}$

Children are the most affected group when it comes to the problems faced by refugees. In many countries, the refugees, especially children, have more serious health problems, higher rate of emergency department admissions and more hospital admissions than local residents. ${ }^{[12-16]}$ There is a limited amount of information in the literature on the needs of refugees and the services provided to them. The health problems of refugees located in camps or temporary settlements are relatively foreseeable, controllable and treatable and it is easier to evaluate them. There are few studies about the health problems of unregistered and unrecorded freely moving Syrian refugees.

In this study, our aim was to identify the characteristics of the refugees who apply to our pediatric emergency clinic and pediatric outpatient clinics and to identify the reasons of health problems for their applications. Our aim was to determine and contribute to the necessary health precautions for the refugee children.

\section{MATERIAL AND METHOD}

This was a retrospective patient file review study, which was conducted in a multidisciplinary teaching and research hospital in Ankara, Turkey. The Hospital serves about 100000 children annually in the pediatric emergency clinic and 90000 children annually in the pediatric outpatient clinics. In the hospital, the pediatric emergency clinic has 16 observatory patient beds for 12 hours short period follow up, the pediatric clinic (in-room service) has 25 patient beds, and pediatric intensive care unit has four patient beds. For this study, ethical approval was obtained from the ethics committee of the Ankara Training and Research Hospital with decision number 390 and date 03/13/2018.

In this study, files of patients admitted to pediatric emergency and outpatient clinics between 1 January 2017 and 31 December 2017 were analyzed retrospectively. The data in the files were recorded which included gender, age, nationality, diagnosis, and whether or not the patients were hospitalized. The patient files of Turkish nationals were excluded and the files of refugees (Syrians, Iraqis, Afghans and others) were studied. The first application of each patient was considered in the study. Recurrent applications were not included. Patients' diagnoses were evaluated according to ICD (International Statistical Classification of Diseases and Related Health Problems) codes.

Statistical analysis of patients' data was performed using the SPSS (v16) program. The Kolmogorov-Smirnov test was used to investigate whether the distribution of continuous numerical variables is close to normal. Descriptive statistics were given as mean \pm standard deviation, as their distributions were normal. Descriptive statistics for categorical variables were presented as number of cases and per cents.

\section{RESULTS}

During the study period, there were a total of 109994 applications to the pediatric emergency clinic; 50948 of these were recurrent applications which were not taken into account. Of the remaining 59046 applications, 12385 (21\%) were refugee applications. Among the refugee children, $55.6 \%(n=6,890)$ were male, the mean age was $4.7 \pm 3.8$ years and $69.1 \%(n=8,559)$ were under five years of age. The distribution of the nationality of the refugee children were $50.6 \%(n=6,262)$ Iraqi, $46.2 \%(n=5,724)$ Syrian, $1.2 \%(n=148)$ Afghan, and $2 \%$ from other countries ( $n=251)$.

The diagnosis of refugee children admitted to the pediatric emergency clinic in order of frequency were upper respiratory tract infections (URTI), lower respiratory tract infections (LRTI), acute gastroenteritis (AGE), and skin infections. 21.4\% of these patients $(n=2,612)$ were admitted to the pediatric clinic or the pediatric intensive care unit. Of these patients, some were hospitalized for infectious diseases: $1.1 \%$ Varicella $(n=138)$ and $0.8 \%$ Hepatitis $A(n=92)$. Malnutrition was diagnosed in $6.2 \%(n=771)$ of the patients (Table 1$)$. 
Table 1. Characteristics of refugees admitting to the pediatric emergency clinic $(n=12,385)$

\begin{tabular}{lcc} 
& $\mathbf{n}$ & $\%$ \\
\hline Gender & 5495 & \\
Female & 6890 & 44.4 \\
Male & & 55.6 \\
Age (month) & 1235 & \\
$\quad$ <12 months & 6047 & 9.9 \\
13-36 months & 1277 & 48.9 \\
37-60 months & 3826 & 10.3 \\
>61 months & & 30.9 \\
Nationality & 5724 & \\
Syria & 6262 & 46.2 \\
Iraq & 148 & 50.6 \\
Afghanistan & 251 & 1.2 \\
Other & & 2.0 \\
Most common diagnosis * & 4238 & \\
URTI & 1579 & 34.2 \\
LRTI & 2011 & 12.7 \\
AGE & 771 & 16.2 \\
Malnutrition & 545 & 6.2 \\
UTI & 477 & 4.4 \\
General physical examination & 254 & 3.9 \\
Dermatitis & 228 & 2.0 \\
Urticaria & 221 & 1.8 \\
Conjunctivitis & 138 & 1.8 \\
Varicella & 114 & 1.1 \\
Febrile convulsion & 107 & 0.9 \\
Thalassemia & 92 \\
Hepatitis A & 81 & 0.9 \\
Celulitis & 60.9 \\
Epilepsy & & 0.8 \\
Hospitalized patients & & 0.7 \\
Yes & & 0.5 \\
No & & \\
\hline
\end{tabular}

A total of 91791 patients were admitted to the outpatient pediatrics clinics during the study period. 57907 of these applications were recurrent applications. After excluding recurrent admissions, 33884 patients were included in the study. $24.6 \%(n=8341)$ of these applicants were refugee children. Among these, $50.9 \%(n=4243)$ were male, the mean age was $9.1 \pm 5.5$ years and $55.4 \%$ of the children $(n=4622)$ were under the age of five. The distribution of the nationality of the refugee children were $51.9 \%(n=4329)$ Syrian, $45.9 \%$ $(n=3827)$ Iraqi, $0.9 \%(n=78)$ Afghan, and $1.3 \%(n=107)$ from other countries.

The diagnosis of refugee children admitted to the outpatient pediatrics clinics in order of URTI, LRTI, AGE and urinary tract infections (UTI). As seen in Table 2, 23.8\% of the patients were diagnosed with anemia caused by iron deficiency, 9.6\% were diagnosed with vitamin B12 deficiency, and $0.9 \%$ were diagnosed with thalassemia. Among the refugee children admitted to the pediatric outpatient clinics, $0.5 \%(n=38)$ of them were hospitalized in the pediatric clinic.
Table 2. Characteristics of refugee children admitted to the outpatient pediatrics clinics $(n=8,341)$

\begin{tabular}{|c|c|c|}
\hline & $\mathbf{n}$ & $\%$ \\
\hline \multicolumn{3}{|l|}{ Gender } \\
\hline Female & 4098 & 49.1 \\
\hline Male & 4243 & 50.9 \\
\hline \multicolumn{3}{|l|}{ Age (month) } \\
\hline$<12$ months & 1368 & 16.4 \\
\hline $13-36$ months & 2060 & 24.7 \\
\hline $37-60$ months & 1194 & 14.3 \\
\hline$>61$ months & 3719 & 44.6 \\
\hline \multicolumn{3}{|l|}{ Nationality } \\
\hline Syria & 4329 & 51.9 \\
\hline Iraq & 3827 & 45.9 \\
\hline Afghanistan & 78 & 0.9 \\
\hline Other & 107 & 1.3 \\
\hline \multicolumn{3}{|l|}{ Most common diagnosis * } \\
\hline URTI & 2609 & 31.3 \\
\hline Iron deficiency anemia & 1981 & 23.8 \\
\hline AGE & 1861 & 22.3 \\
\hline UTI & 1331 & 16.0 \\
\hline LRTI & 1026 & 12.3 \\
\hline B12 deficiency anemia & 799 & 9.6 \\
\hline General physical examination & 547 & 6.6 \\
\hline Abdominal pain & 402 & 4.8 \\
\hline Fever & 343 & 4.1 \\
\hline Conjunctivitis & 215 & 2.6 \\
\hline \multicolumn{3}{|l|}{ Hospitalized patients } \\
\hline Yes & 38 & 0.5 \\
\hline No & 8303 & 99.5 \\
\hline
\end{tabular}

\section{DISCUSSION}

In countries where there are refugees, they experience problems such as language barriers, difficulties in reaching social services, nutrition problems due to low economic levels, and housing problems. Therefore, refugees are the most susceptible groups to health problems. ${ }^{[17]}$ Women, elderly and children with developmental needs are more prevalent and they are the most vulnerable groups experiencing health problems within refugees. ${ }^{[3,17]}$ When refugees have health problems, they often apply to the emergency clinics in hospitals because of financial problems they face and their lack of health insurance. ${ }^{[18,19]}$

A study about Syrian refugiess in Turkey published in 2014 reports that Syrian refugees constitute $10 \%$ of the total number of applications in the emergency service applications, especially in cities along the Syrian border. ${ }^{[19]}$ Yurtseven et al. ${ }^{[20]}$ reported that $0.4 \%$ of the applications to the pediatric emergency clinics in İmir were Syrian refugees during the period between January 2014 and December 2014. Ozdemir et al. ${ }^{[14]}$ in 2014, in a study conducted in Adana, reported that $2.53 \%$ of patients admitted to the pediatric emergency clinics were refugees. In our study, between January 2017 and December 2017, 21\% of pediatric emergency applications were made by refugees, $46 \%$ of whom were Syrians and $50.6 \%$ 
were Iraqis. Among a total of 8341 refugee children in the outpatient pediatric clinics applications 4329 (51.9\%) were Syrian refugee children. Compared with other studies, we found that there has been a significant increase in the number of refugee children applications over the past three years. The numbers suggest that the increase in the number of refugees coming to Turkey in recent years has led to an increase in hospital applications.

The number of applications to pediatric emergency clinic was higher than the number of applications to the outpatient pediatric clinics. It was seen that more Iraqi refugees were admitted to pediatric emergency than pediatric outpatient clinics. It is thought that Iraqi refugees have more emergency applications due to ID card problems and financial reasons, since applying to the outpatient clinics without an ID card requires a fee payment while no payment is required in the emergency clinic.

The inadequate care given to children, financial difficulties, and low level of education are among the causes for families' inability to protect their children from sickness and accidents. Weak and vulnerable young children are exposed to much more health problems..$^{[5,10,21]}$ It has been reported in other studies that emergency and outpatient clinics admissions of young children under the age of five are more frequent. In the study by Bucak et al. ${ }^{[5]} 69.2 \%$ of Syrian refugees who applied to clinics were under five years old; this ratio was given as $56.3 \%$ in the study of Aygün et al. ${ }^{[22]}$ Similarly, the majority of refugee children who applied to both the emergency department (69.1\%) and the outpatient pediatrics clinics (55.4\%) were under the age of five in this study.

A refugee's life is often quite challenging because of the difficulty they face to obtain basic needs such as shelter, food, and water. Thus, refugees can be highly susceptible to infections for various reasons, including living outdoors in open areas, crowded and unsanitary living conditions, low standards of environmental hygiene, unsafe food and water, starvation, interrupted immunization programs, inhibitions in local healthcare settings, and limited access to health care services. For these reasons, refugees are prone to bacterial and viral respiratory system infections, including influenza, measles, mumps, tuberculosis and meningococcal infections, gastrointestinal system infections, skin and soft tissue infections, and vector-borne infections. ${ }^{[22-24]}$ In their study in Lebanon, Beldjebel et al. ${ }^{[25]}$ reported that the most common presenting complaints in Syrian and Iraqi refugee children was gastrointestinal system symptoms and $90 \%$ of these were infected with infectious diseases. Bucak et al. ${ }^{[5]}$ reported the most frequent diseases were AGE and LRTI in Syrian refugee children admissions to hospital. In another study, URTI, LRTI and AGE were most frequently reported in Syrian populations in pediatric emergency applications. ${ }^{[20]}$ Regardless of ethnicity, infectious diseases are the most common reasons for pediatric emergency applications. Karakaş et al. ${ }^{[26]}$ support this observation in their study about reasons for pediatric emergency applications. This study is in agreement with the literature, acute infectious diseases including URTI, LRTI and AGE were also the most common causes for hospital admisions.

The prevalence of varicella and hepatitis $A$ infections were $1.1 \%(n=138)$ and $0.8 \%(n=92)$ in our study group. One study of Syrian refugee children who had settled in Germany revealed that $11 \%$ of 488 children had been diagnosed with active tuberculosis and $9 \%$ with chronic hepatitis B or C, which are noteworthy figures. ${ }^{[27]}$ We encountered no record concerning tuberculosis or chronic hepatitis in the children in our study. The prevalence of hepatitis A diseases in Syrian refugees recorded by the Public Health Service in 2012 was 718 cases and 25 cases in $2015{ }^{[28]}$ No publication has been found in the literature on the prevalance of hepatitis $A$ in refugee children. We think refugees that do not remain at the camps and migrate to various cities in Turkey, should be vaccinated regularly and a strict control of refugee children's vaccination status could reduce vaccine-preventable infectious diseases.

In our study, anemia was detected in $34.3 \%$ of the refugees. Anemia caused by iron deficiency in $23.8 \%$, vitamin B12 deficiency in $9.6 \%$, as well as thalassemia in $0.9 \%$ of the refugee applications. In a study conducted in Turkey, nutritional anemia was reported in $50 \%$ of the refugee applicants. ${ }^{[5]}$ Iron deficiency caused by anemia is reported to reach $30 \%$ levels independent of the refugee applications in various national pediatric patient data. ${ }^{[29,30]}$ Results of this study are in agreement with national data. The evolving nutritional anemia due to malnutrition is thought to be a major health problem in addition to the acute infections encountered in refugee children. Iron and B12 deficiency anemia are important causes of preventable anemia. Therefore, we think that refugee children must be evaluated in this respect whatever the reasons for their application. Bucak et al. ${ }^{[5]}$ reported that they diagnosed beta thalassemia major in $3.8 \%$ of refugee children who applied to the pediatric clinic in their study; in our study $0.9 \%(n=107)$ of the cases were diagnosed. Thalassemia patients could not be examined in the pediatric hematology clinic due to their lack of ID cards. Erythrocyte transfusions treatments were given to the refugee thalassemia children at pediatric emergency clinic during recurrent referrals.

Frequent health problems in refugee children can lead to frequent hospitalization. Especially refugees who do not have health insurance cannot access preventive health care and/ or be referred to health facilities in the early stages of their illness; as a result, their need for hospitalization or intensive care services ultimately increase. ${ }^{[14,18,20]}$ Yurtseven et al. ${ }^{[20]}$ found that the rate of hospitalization for Syrian patients was $14.2 \%$. In our study, $21.4 \%(n=2,612)$ of refugee children who were admitted to the pediatric emergency clinic and $0.5 \%$ $(n=38)$ of refugee children who were admitted to pediatric outpatient clinics were hospitalized in pediatric clinics or pediatric intensive care units. Hospitalization rate was less frequent in the pediatric outpatient clinics. We think that the 
reason for this is that the Iraqi patients who do not have social security and the refugees who have expired ID cards apply to emergency services only, where they can be looked at free of charge until their ID cards are renewed.

The increase in the number of refugees in Turkey and their health should be carefully considered and their living conditions should be improved. During every hospital application of refugee children, their vaccination status should be questioned and vaccination plans for children with missing vaccinations should be made. Refugee children's development should be closely monitored, especially in terms of malnutrition, iron deficiency, and other mineral and vitamin deficiency and for this purpose establishing polyclinics that are designed for refugee needs, including language support, may be helpful.

\section{CONTRIBUTION TO LITERATURE}

The main contribution of this study is that it provides a picture of the recent status of refugee children's health and recommendations for improvement. In this study, which was conducted in a city far away from the Syrian border, the ratios of admission to pediatric emergency and outpatient clinics and hospitalizations were high in a one-year period compared to previous studies. Syrian and Iraqi refugees constitute almost all of the refugee applications and half of the total hospital applications. It was seen that the rate of applications for children under the age of five was highest. The most common reasons for referral were infectious diseases and anemia.

Regarding the reasons for the applications, it seems that active use of primary care services by refugees would prevent most of the illnesses. We recommend that every refugee child should be scanned for malnutrition and anemia (that iron, vitamin B12 and thalassemia) and defined nutritional support should be provided, if necessary, to preserve the health status of such individuals.

\section{ETHICAL DECLARATIONS}

Ethics Committee Approval: For this study, ethical approval was obtained from the ethics committee of the Ankara Training and Research Hospital with decision number 390 and date 03/13/2018.

Informed Consent: Because the study was designed retrospectively, no written informed consent form was obtained from patients.

Referee Evaluation Process: Externally peer-reviewed.

Conflict of Interest Statement: The authors have no conflicts of interest to declare.

Financial Disclosure: The authors declared that this study has received no financial support.

Author Contributions: All of the authors declare that they have all participated in the design, execution, and analysis of the paper, and that they have approved the final version.

\section{REFERENCES}

1. Doganay M, Demiraslan H. Refugees of the Syrian civil war: impact on reemerging infections, health services, and biosecurity in Turkey. Health Secur 2016;14(4):220-5.

2. Giannakopoulos G, Anagnostopoulos DC. Child health, the refugees crisis, and economic recession in Greece. Lancet 2016;387(10025):1271.

3. Turkish Ministry of Interior Directorate General for Immigration 2018 datas www.goc.gov.tr Accessed May 16, 2018.

4. United Nations High Commissioner for Refugees. UNHCR Global Appeal 2015. http://www.unhcr.org/5461e60716.html. Accessed April 30, 2018.

5. Bucak IH, Almis H, Benli S, Turgut M. An overview of the health status of Syrian refugee children in a tertiary hospital in Turkey. Avicenna J Med 2017;7(3):110-4

6. Doner P, Ozkara A, Kahveci R. Syrian refugees in Turkey: numbers and emotions. Lancet 2013;382(9894):764.

7. Doocy S, Lyles E, Akhu-Zaheya L, Burton A, Weiss W. Health service utilization and access to medicines among Syrian refugee children in Jordan. Int J Health Plann Manage 2016;31(1):97-112.

8. Guha-Sapir D, Panhuis WG. Conflict-related mortality: An analysis of 37 datasets. Disasters 2004;28(4):418-28.

9. Turkay M. Children's Problems. War, migration and health. Publications of Turkish Nationalities Union: Ankara 2016:71-5.

10. Aydın D, Sahin N, Akay B. Effects of immigration on children's health Behcet Uz Cocuk Hast Derg 2017;7(1):8-14.

11. Gumuş Y, Bilgili N. The effects of immigration on health. J Anatolia Nurs Health Sci 2015;18(1):63-7.

12. Beniflah JD, Little WK, Simon HK, Sturm J. Effects of immigration enforcement legislation on Hispanic pediatric patient visits to the pediatric emergency department. Clin Pediatr 2013;52(12):1122-6.

13. Hargreaves S, Friedland JS, Gothard P, et al. Impact on and use of health services bu international migrants:questionnaire survey of inner city London A\&E attenders. BMC Health Serv Res 2006;6(1):153.

14. Ozdemir U, Tolunay O, Atmış A, et al. Characteristics of refugee patients followed in the Pediatric Intensive Care. J Pediatr Emerg Intensive Care Med 2016;3(2):86-90.

15. Ozdogan HK, Karateke F, Ozdogan M, Satar S. Syrian refugees in Turkey: effects on intensive care. Lancet 2014;384(9952):1427-8.

16. Pedgore JK, Rene A, Sandhu R, Marshall M. A health assessment of refugee children from former Yugoslavia in Tarrant County. Tex Med 2003;99(6):50-3.

17. Karadag O, Altıntaş K.H. Refugees and Health. TAF Prev Med Bull 2010;9(1):55-62.

18. Deans AK, Boerma CJ, Fordyce J, De Souza M, Palmer DJ, Davis JS. Use of Royal Darwin Hospital emergency department by immigration detainees in 2011. Med J Aust 2013;199(11):776-8.

19. Korkmaz AÇ. Problems caused by asylum seekers in health and nursing services. J Health and Nursing Management 2014;1(1):37-42.

20. Yurtseven A, Ozcan G, Saz EU. Comparison of between Syrian patients and Turkish patients who admitted to the pediatric emergency department: Experince of Ege University J Pediatr Emerg Intensive Care Med 2015;2(1):133-6.

21. Ozservet $Y$, Sirkeci E. from the Editor:Children and migration. Göç Derg 2016;3(1):1-4.

22. Aygün O, Gokdemir O, Bulut U, Yaprak S, Guldal D. Evaluation of Primary Health Care Services which is provided to refugees within a Public Health Center. TJFM\&PC 2016;10(1):6-12.

23. Leblebicioglu $H$, Ozaras $R$. Syrian refugees and infectious disease challenges. Travel Med Infect Dis 2015;13(6):443-4.

24. Ozaras R, Leblebicioglu $H$, Sunbul $M$, et al. The Syrian conflict and infectious diseases. Expert Rev Anti Infect Ther 2016;14(6):547-55.

25. Beldjebel I. Infectious diseases in refugees coming from Syria and Iraq to Lebanon. Int J Infect Dis 2014;21(1):1-40. 
26. Karakaş NM, Özdemir B, Kılıç S, Akbulut Ö. Causes of Pediatric Emergency Department Applications of Parents: 4 Years Follow-Up. Osmangazi J Med. 2020;42(1):67-74.

27. Mockenhaupt FP, Barbre $K A$, Jensenius $M$, et al. Profile of illness in Syrian refugees: A GeoSentinel analysis, 2013 to 2015. Euro Surveill. 2016;21(10):30160.

28. Health Statistics Yearbook 2014, Republic of Turkey, Ministry of Health http://www.saglik.gov.tr/TR/dosya/1-100379/h/eng-yillik. PDF Accessed May 16, 2018.

29. Sanlı C, Kocak U, Albayrak M, et al. Frequency of iron deficiency anemia in children who were admitted to Kırıkkale University Medical School Hospital and its association with nutrition. Çocuk Derg 2005;5(3):184-9.

30. Kucuk O, Gocmen AY, Bicer S. Prevalence of iron deficiency anaemia in children with poor appetite. Bozok Tıp Derg 2013; 3(2):37-41. 